\title{
PROJECT “EXCHANGE OF SECONDARY RAW MATERIALS AND TECHNOLOGY BETWEEN NORTHWEST RUSSIA AND SOUTHEAST FINLAND": PERSPECTIVES AND OPPORTUNITIES
}

\author{
Maria Lyubarskaya \\ Vadim Chekalin
}

St. Petersburg State University of Engineering and Economics, Russia

\begin{abstract}
Waste management and utilization of waste materials are current and remarkable problems in Nordic Countries and, especially, in Russia. In the city of St. Petersburg and Leningrad oblast waste causes a difficult environmental and health problem because plenty of waste is left to the environment without relevant handling. As a result, it is obvious that a negative environmental impact will occur to the whole region of Gulf of Finland. It is possible to develop joint solutions for the waste problems in cooperation between Russian and Finnish parties especially for the regions in the adjacent areas of the border. Increasing of volumes improves the profitability of waste utilization and makes it easier to execute the necessary investments. This favours the exchange and trade of materials derived and/or refined from waste and necessary technologies, between Russian and Finnish actors.
\end{abstract}

TASIC project "Exchange of secondary raw materials and technology between Northwest Russia and Southeast Finland" is financing by the European Community, represented by the Commission of the European Communities.

\section{KEYWORDS}

Utilization of waste materials; Legislation base for by-product transportation; Supply and demand of waste materials; Technologies and services; Web-portal "Material and Technology Exchange".

\section{INTRODUCTION}

The main objective of the project is to develop the environmental line of business by creating new means for cross-border trade of environmental services, technologies and materials in the region of Southeast Finland and the region of Northwest Russia including St. Petersburg and Leningrad oblast. A functional objective is to develop a tool for material (refined from byproducts and waste materials), service and technology change between Northwest Russia and Southeast Finland. This so called Material Exchange portal would be a common tool for Finnish and Russian enterprises in management of environmental trade. The intention is to create profitable, international co-operation during the project. One objective is to find out the supply and demand of waste and secondary raw materials in Finland and in Russia and to look 
into the most efficient ways of doing business considering the life cycle costs, optimising the recovery rate and minimizing the environmental impacts of waste utilization. Another objective is to find out technology and equipment for solid waste processing, including recycling, composting and energy production. And at last third objective is to develop logistics chains in the field of waste management, including waste recycling and re-using, organizing training and re-training programs and consulting services for local authority representatives and specialists in solid waste management (SWM). A long-term objective is to raise the level of SWM in the Northwest region of Russia.

\section{MODULES OF THE PROJECT}

The project can be divided into the following smaller modules:

a. A research on the amounts of supply and demand of materials, technologies and services in St Petersburg and Leningrad oblast, and how the materials can be provided considering the life cycle costs and environmental impacts; defining suitable materials in the regions of St Petersburg and Leningrad oblast' for integrated utilization between Russia and Finland. This information is needed for the starting Material and Technology Exchange portal and practical trade. It is also needed for Finnish partners to find the potential and suitable solutions for Finnish materials and utilization development.

b. A study about the Russian legislative rules including restrictions and pre-conditions concerning by-product transport from Russia to Finland and from Finland to Russia.

c. Development of the web-portal "Material and Technology Exchange" as a part of the Finnish portal developed now by Hyötyvisio Oy, Finland in the framework of the Interreg-part of the project that would lead to creation of a joint Russian - Finnish webportal. This portal will assist in environmental trade and creation of the business model for environmental trade in cooperation with the earlier started Interreg project 'Material Exchange', administrated by Lappeenranta University of Technology.

d. Development of the model for the Material and Technology Exchange. Assembling of the actor network and piloting the service in the Russian side of the border.

e. Training and dissemination of the project in special seminars and the international conference, and also in printed information materials.

f. Starting the material, product and technology trade between Russia and Finland in practice: arrangements of 1 or 2 pilot cases in St Petersburg and Leningrad oblast will be executed by ENGECON in cooperation with the Russian subcontractor. The project will show one kind of operations which could be realized in the Ecopark of Leningrad oblast' which was developed in the Interreg-project "Development of Ecopark of Leningrad oblast" " and will be developed also in a TACIS-project (processing and refining of materials can be executed in future in Russian Ecopark). The projects will co-operate.

g. Transfer to sustainable commercial operating of the exchange.

The project supports development of cross-border co-operation in the regions of Southeast Finland and regions of St. Petersburg and Leningrad Oblast by the following ways (related to the lines and measures of the program): 
- Export possibilities of enterprises from near-border regions of the adjacent countries working in the field of environmental technology will be supported by developing the tool for finding customers and partners in the neighbour countries and by promoting the networking of the companies. Most of the environmental companies are small in the region of St Petersburg and Leningrad oblast and many studies have shown that co-operation and networking between companies is the way to develop by increase their busyness export possibilities.

- Finnish-Russian research co-operation will be concretised by carrying out research on waste materials and their utilization possibilities in both sides of the border. Knowhow in waste management and utilization will be increased.

- Rationalization of waste utilization by integration of the flows of the waste derived materials will increase the utilization rate of waste and improve the waste management especially in Russia.

- Stimulation environmental innovation activities by promoting of innovative technologies

- Organizing of training and re-training programs and also consulting service for representatives from local authorities and specialists in SWM, which will contain several parts devoted to the following issues: Legal base, Organizational chart, Financial and economic analysis, Environmental analysis, Technical and technological analysis, Informational base, Psychological base.

\section{AMOUNTS OF SUPPLY AND DEMAND OF MATERIALS, TECHNOLOGIES AND SERVICES IN NORTHWEST RUSSIA}

More than six million people live in the area of St. Petersburg and Leningrad oblast. SWM in this area is currently insufficient. Thus, utilization of some of their recyclable materials in Finnish waste handling processes could serve everyone's needs. There are also such Finnish waste materials, which do not have rational utilization possibilities in Finland but could be utilized in Russia. Also refining possibilities of by-products in the area of St. Petersburg and the Leningrad region can be better in some cases.

There is both supply and demand for such recyclable materials and secondary raw materials, which have positive market value. Such materials are for example paper, cardboard, metals, plastics and lime. Besides, new innovation technologies and related equipment are developing both in Northwest Russia and Southeast Finland. These and other potential material and technology streams will be analysed in this part of the project to determine:

Which Finnish materials and technologies could be utilized in Russia and what kind of Russian materials and technologies could be utilized in Finland? What are the amounts of recyclable fractions of the material flows?

How much would it approximately cost to collect, handle, refine and utilize the potential material fractions when they are integrated together, compared to separate management in both countries?

What would be the effect of the increase of refining degree by more complicated separation methods to different recyclable material flows?

What kinds of technologies and services will be needed to develop the business for waste management, recycling and other kinds of environmental technologies? 
It is possible to carry out the study considering the life cycle costs of waste management and utilization.

Environmental impacts of recycling options will be studied and compared with each other. The replacement of virgin materials and fossil energy with recycled materials (utilized as secondary raw material or energy) will be studied. Also consumption of energy for the recycling will be studied and compared to cases when recycling is not done. Research part of the project will be carried out by ENGECON because it has extensive and profound experience on research of material flows, waste management, waste utilization and environmental impacts. For this purpose a special questionnaire will be developed and spread potential Russian participants of the web-portal. Selection of a subcontractor who has more information on details of advanced information technologies is guessed through the bidding procedure. The selected subcontractor will carry out a part of this study.

\section{LEGISLATION BASE FOR BY-PRODUCT TRANSPORTATION}

The project includes research on transportations of secondary raw materials through the border between Russia and Finland. Russian legislation, EU legislation and international treaties set certain boundaries on what type of materials can be imported/exported and on what conditions. During this part of the project, research is made on the legal requirements of transporting waste derived materials between Russia and Finland. The subcontractor will be chosen also because ENGECON does not have the necessary resources for legislative studies for the project.

\section{DEVELOPMENT OF THE RUSSIAN PART OF THE RUSSIAN-FINNISH WEB- PORTAL "MATERIAL AND TECHNOLOGY EXCHANGE"}

The co-operation between the web-portal services in Finland and in Russia will be built on the basis of co-operation between ENGECON and the subcontractor from the Russian side and LUT and Hyötyvisio Oy from the Finnish side. Finnish partners are now the participants of the Interreg project 'Material Exchange'. The idea is to create a channel of trade for the SMEs and to other communities in both sides of the border. Using the portal services makes it easier to begin international trade. The goal is to develop a partnership, which all the parties can benefit from. Also the legal requirements have to be cleared. There are examples of such Internet portals in Finland and Russia, which are used to exchange secondary raw materials and wastes, and related technologies and services. During the project, a developing Russian portal will be integrated a future joint Finnish - Russian web-portal. It includes planning of the money, material, product and service streams, handling of the customer contacts and passing the offers and invitations for tenders. Principles for e-exchange with taking into account peculiarities of the Russian part will be developed. The initial Russian client base with taking into account requests and proposals from municipal authorities will be created. This part is done with Russian external experts. Simultaneously necessary software based on adaptation the Finnish portal to Russian conditions will be created. The invited subcontractor who will be chosen by the bidding procedure will do this work. Portals have to be integrated so that the work could be flexible and the legal requirements of both parties can be fulfilled. For avoiding misunderstanding between participants the three-language (Russian, Finnish, English) glossary for main terms will be developed. Integrating the web-portals technically is not necessary for the project. Testing of the developed e-exchange with integration of Russian and Finnish parts in the unified portal will be done at the final stage of the project. The main responsibility for this module is from the subcontractor. 


\section{ASSEMBLING OF THE ACTOR NETWORK AND PILOTING THE SERVICE}

For the service to be functional there has to be as many companies as possible using it. Information about the companies and other organizations, which are interested in trading through the service, has to be assembled and these companies have to be informed about the development work. Special requests for client information, first for Russians, and the order of admission with taking into account language of necessary information will be defined. The information and presentation seminar for potential Russian clients (up to 100 participants) will be provided. Simultaneously publishing of the booklet with info on the project, 2000 copies, and e-version at the web site will be done.

The portal makes it easier to begin international business.

The results of the research on the benefits and possibilities of the project will be given to the partner companies. This will give sufficient information of how to benefit from the service, meaning what type of materials, products and services they could trade through the portal. In this phase the results of the research specified in project activity 1 will be utilized. The companies will get the results of a rough market research in exchange for the share of the financing they contribute to the project. After the end of the project the customers will get these results against a specified fee. Network assembly and the piloting of the material exchange service will be implemented in co-operation between ENGECON, LUT, Ekopark and subcontractors. All the partners and co-operation companies are needed in network creation. ENGECON has good contacts in the focus region because of the earlier projects and co-operation there. LUT is a local actor and for that reason have extensive network in the region of Southeast Finland. Subcontract companies are needed to pilot the services, which are in their expert areas and will belong to their future business.

\section{TRAINING AND DISSEMINATION OF PROJECT RESULTS}

For more successful development of the current project special seminars will be provided in St Petersburg:

a. Information and presentation seminar for potential Russian clients (up to 100 participants) at the initial stage of the project. It took place in St-Petersburg, 5-7 of July, 2007.

b. Intermediate Russian - Finnish seminar with presenting the developed product, including special training (up to 100 participants). It took place in Lappeenranta (Finland), 20-22 of September, 2007.

During this training participants receive:

- Knowledge of bases of the integrated organization of SWM and its elements: legislation, information, organization, financial, personnel, psychological;

- Technological and economic aspects of each stage of solid waste handling;

- Skills of the analysis of an initial situation, formation of the target block, the basic directions and the major actions for improving of solid waste handling:

- Skills of marketing researches for consumers and suppliers in solid waste handling, including application of economical and mathematical models for selection of optimal organization chart.

- Principles of using of material and technology e-exchange 
c. Final Russian - Finnish seminar (up to 100 participants). It will take place in StPetersburg, March, 2007. All who interested in given questions are welcome to the seminar.

Publishing of materials of the project will be done also:

The booklet with info on the project, 2000 copies, and e-version at the web site

Information materials on results of the developed product

1-3 articles in scientific journals and conferences

Mutual visits of Russian and Finnish experts for project coordination and information exchange will be provided.

Special business travels in the framework of the case study will be arranged also.

\section{STARTING THE MATERIAL, PRODUCT AND TECHNOLOGY TRADE BETWEEN RUSSIA AND FINLAND IN PRACTICE}

For this purpose $1-2$ pilot cases will be executed by ENGECON in cooperation with the subcontractor. Companies for these cases will be chosen and will be supported by the project. Among measures for realization of the cases will be a special business travel to Finland for establishing direct contact with Finnish partners.

Russian participants of the cases will receive some privileges for their participation in the eexchange after completing the TACIS project.

\section{CO-OPERATION WITH THE OVER PROJECTS IN SOLID WASTE MANAGEMENT SPHERE IN ST-PETERSBURG AND LENINGRAD REGION}

This co-operation is needed first for information dissemination on the current project among companies providing their services in SWM and environmental friendly technologies. Project "Exchange of secondary raw materials and technology between Northwest Russia and Southeast Finland" could be used as an informational donor for development of cooperation between national and international actors in SWM sphere in St-Petersburg and Leningrad region. Seminars show that there is a great interest to such questions from the side of local authorities, private companies, state enterprises and scientific and educational institutes, etc.

\section{TRANSFER TO SUSTAINABLE COMMERCIAL OPERATING OF THE EXCHANGE}

Transfer to sustainable commercial operating of the e-exchange will be ensured by:

a. Introducing special fee from clients.

b. Positive image of e-exchange due to good benefits from the exchange for clients.

c. PR-campaign from the e-exchange administrator. 


\section{CONCLUSIONS}

Many authors comes to conclusion that the one of the major constituents of effective management in any sphere, especially in solid waste management, there is a presence of complete reliable information, necessary for the analysis of the present situation, for creating the strategic plans for development and for acceptance of tactical decisions [1,2]. In Russia, unfortunately, the system of solid waste management to the present tense functions in the conditions of "information insufficiency".

The accumulation of statistical information about the actual volumes of solid waste generation from different sources (population, cultural and administrative establishments, trade organizations, industrial enterprises) in St-Petersburg is very important task. This task will be partly decided in the process of realisation of the "Material Exchange" project.

For increasing of efficiency of solid waste management system's functioning in Northwest Russia and Southeast Finland it is necessary to develop the mechanism for formation of informative, material and technological streams between all of structures, directly participating in this process of SWM or have on him substantial influencing.

In framework of above mentioned task the project "Exchange of secondary raw materials and technology between Northwest Russia and Southeast Finland" will allow:

- To provide all of the interested participants of solid waste management process by necessary information;

- To provide a basis for development of the solid waste management strategy, this meets the proper modern needs of concrete region;

- To create and conduct the analysis of informative, financial, material and technological streams between Northwest Russia and Southeast Finland in the field of SWM;

- To optimize transport streams in the field of SWM in the region;

- To organise monitoring of changes of external and internal descriptions of functioning of the SWM system in region.

The realisation of "Material Exchange" project, sure, will demand certain financial and human recourses on the initial stage, but in future it will allow cutting down expenses and increasing the incomes on functioning of the SWM systems in Northwest Russia and Southeast Finland.

In future the area of this project could be extended on the Nordic Countries and on other countries of the Europe which are interested in cooperation with Russia in the questions of solid waste management, especially in informational, material and technological exchange.

\section{REFERENCES}

[1] Diaz, L. F., Savage G. M., Eggerth L. L., Golueke C. G., 1996. Solid Waste Management for Economically Developing Countries. Hercules, California. 417.

[2] Chekalin, V.S., Luybarskaya, M.A., 2006. Problems of Solid Waste Management in StPetersburg and the Way of Their Solving. EURO-ECO-2006, 8-9. 